\title{
The Education System as a Determining Factor in the Quality of Human Capital in the Digital Economy
}

\author{
Natalia Rybalko \\ Department of Economics and Finance \\ of the Humanitarian and pedagogical Academy (branch) \\ V. I. Vernadsky Crimean Federal University \\ Yalta, Russia \\ natr19@mail.ru
}

\author{
Svetlana Arkhipova \\ Department of Economics and Finance \\ of the Humanitarian and pedagogical Academy (branch) \\ V. I. Vernadsky Crimean Federal University \\ Yalta, Russia \\ stavrsveta@rambler.ru
}

\begin{abstract}
The article deals with the organization of the education system in relation to the quality of human capital in the modern conditions of digitalization of the economy. The structure of education in Russia is given. Statistical data on the education levels of the adult population in Russia per 1000 population dynamics of expenditure on education in the Russian Federation, the dynamics of the number of students by level of education, structure of issue in a individual large groups of occupations skilled workers and employees, mid-level professionals, as well as bachelors, specialists, masters are analyzed. The composition of the employed population by level of education is analyzed. The prospects for further development of the education system in the digital economy are outlined. It is determined that education accompanies a person throughout life: at the stage of" formation", the foundations are formed for further formation and systematization of knowledge. At the stage of "accumulation", the necessary knowledge that are included in the competences in accordance with the specialization and qualification of the student are developed. In the "use" stage, the knowledge gained in the previous stages is used for the social reproduction. At the stage of "reproduction", the influence of the received education on the life of a person and his family is manifested. The education system generates a certain level of human capital. Digital technologies are actively used, both at the level of acquired competencies and at the level of tools used in the educational process at all levels of education.
\end{abstract}

Keywords-education system, human capital, digital economy, education levels, groups of professions, employment.

\section{INTRODUCTION}

Research in the field of human capital in recent conditions is proves to be relevant. The development of the digital economy determines the growing role of education, sets new competencies and requirements for learning outcomes and transforms existing ones. Education capital is one of the components of human capital that largely determines socio-economic development.

Human capital is the subject of research by modern scientists such as Zabelina O. V., Kozlova T. M., Romanyuk A.V. [5], Pivovarov V. I., Mazur V. V. [8] and others. The role of education in the formation and development of human capital is studied in the works of such scientists: Budzinskaya O. V., Demidova A.V. [3], Khadzhalova Kh. M. [10], Golovina S. G., Mikolaychik I. N., Smirnova L. N. [4], Khanova O. Yu., Kudryashova O. K. [11], Kasaeva T. V., Esankulova D. A. [6], Nozhkina E. B., Mavlyutova G. A., Altukhov P. L. [13], Uvarov A. Yu., Gable E., Dvoretskaya I. V. et al [14], Bourdieu, P. [15], Tolstykh T., Vertakova Y., Shkarupeta E., Shishkin I. and Krivyakin K. [16] and others.

The purpose of the publication is to study the current state of the education system, taking into account the impact of the development of the digital economy, to identify the main trends and prospects. The objectives of the study are: defining the role of education in the system of formation and employment of human capital by the main stages, defining the structure of the education system in Russia, analyzing the main statistical data characterizing education in terms of the state of human capital and identifying development prospects.

\section{METHODS}

The research methods are as follows: data systematization, synthesis, analysis, index method, trend detection method, horizontal analysis. 


\section{MAIN PART}

Human capital is the most important resource in any type of production system. The formation of human capital is carried out under the influence of a large number of external and internal factors, depends on many objective and subjective variables. In the scientific literature, various components of human capital are distinguished, however, in most cases these are: health capital, education capital, culture capital.

In recent conditions of the formation of the digitalization of economy, it is the knowledge embodied in the productive force that determines the efficiency of the economy at the micro and macro levels. G. Becker in his scientific works substantiated that education increases labor productivity [2]. T. Schultz considered education as capital [12].

The spheres of education and science play a key role in the development of the country and each individual region, having a significant impact on the economic, social and cultural aspects of the life of the population. In fact their influence is due not only to the assumed direct correlation between the industry structure of the region's economy, but also to the need for certain specialists. The reverse process also takes place, when the activity of universities (educational and scientific activities, first of all) determines the structure of employment, the dynamics of development of economic sectors and, as a consequence, the success of Russian regions (oblasts) [4, p.12]. The capital of education as a set of skills, abilities, intelligence, health and professionalism is recognized by most researchers as fundamental constituent in the formation of human capital. The importance of education capital as a fundamental component of human capital is due to the fact that it is it that determines the level of an individual's income [6, p.13]. It is noted that the capital of education is a set of economic relations arising in social production between its subjects regarding the formation, development and consumption of human intellectual abilities in the form of knowledge that has potential value $[5$, p.54]. In modern society, knowledge is not a individual resource, nor a individually created goods. They are embedded in a single multidimensional economic system of economic relations regarding the production, knowledge distribution and application; they should be considered as an element of a more complex and general system of social relations as a whole [11]. Education is one of the tools for formation a system for building up human capital in society. It is the level of human capital and its share in the overall structure of national wealth that are indicators of the development of society. It is the value of education and the confidence of the population in its influence on the level of income in the future that make it possible to create the basis for investment in education [3, p.141]. Definition of human capital as a kind of stock of knowledge, as well as the possibility of using this stock of knowledge, allows us to understand human capital as a "stock" of knowledge and professional experience accumulated by a person as a result of training, selfeducation and socialization, which a person can use when he is included in the capital turnover process. [8, p.79].

Education plays an important role in the system of formation and use of human capital at all stages: formation, accumulation, use and reproduction (table 1).

At the first stage - formation stage - education is the task and responsibility of the family. Here the foundations are laid, the foundation basis for the subsequent formation and systematization of knowledge.

TABLE I. THE ROLE OF EDUCATION IN THE SYSTEM OF FORMATION AND EMPLOYMENT OF HUMAN CAPITAL [10, P.25]

\begin{tabular}{|c|l|}
\hline $\begin{array}{c}\text { Stages of formation and employment of } \\
\text { human capital }\end{array}$ & \multicolumn{1}{c|}{ Content } \\
\hline Formation & $\begin{array}{l}\text { The main role of investment in the education of individuals is played by the family. The family invests } \\
\text { in the education of children in order to earn a high income in the future }\end{array}$ \\
\hline Accumulation & Investment in an individual's education is carried out by state institutions \\
\hline Using & The education received by an individual is decisive in the process of its use in professional activities \\
\hline Reproduction & $\begin{array}{l}\text { Education affects the lifestyle of an individual and their environment. The actual abilities of the } \\
\text { individual are reproduced }\end{array}$ \\
\hline
\end{tabular}

At the second stage - accumulation - the student receives knowledge of the professional environment, the future profession. This is where certain competencies, specialization and qualifications are formed. At the third stage - use - the practical application of the knowledge gained in the first two stages takes place, the "usefulness" of the knowledge gained for the social reproduction of goods and services is determined. At the fourth stage - reproduction- the level of education influences the life of a person and his family. Ensuring an effective education system is one of the most important social tasks of the state. The higher the level of education in society, the more efficient the production process will be, which directly affects the socioeconomic development of the state.
The structure of the education system in Russia (figure 1) is approved by the Federal Law of December

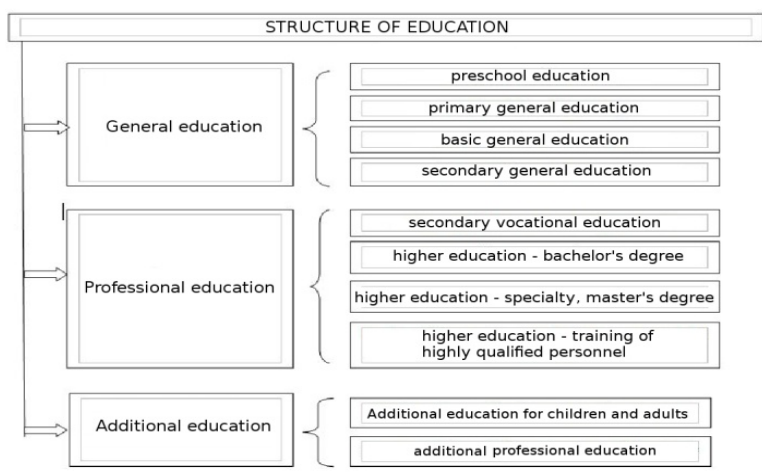


29, 2012. No. 273-FZ "On Education in the Russian Federation". Education is subdivided into general education, vocational education, additional education and vocational training, which ensure the possibility of realizing the right to education throughout life (lifelong education) [1]. Let's analyze statistical data that will allow us to assess the education system development, taking into account the influence of the digital economy development factor on the human capital quality. Figure 2 contains data on the education level of the adult population in Russia per 1000 people. According to figure 2, the largest number (per 1000 people in this age group who indicated the education level) equals to 347 programs for middle-level specialists. 304 people have higher education (per 1000 people in this age group who indicated their level of education). people has secondary vocational education in training.

Fig. 1. Structure of the education system [1]

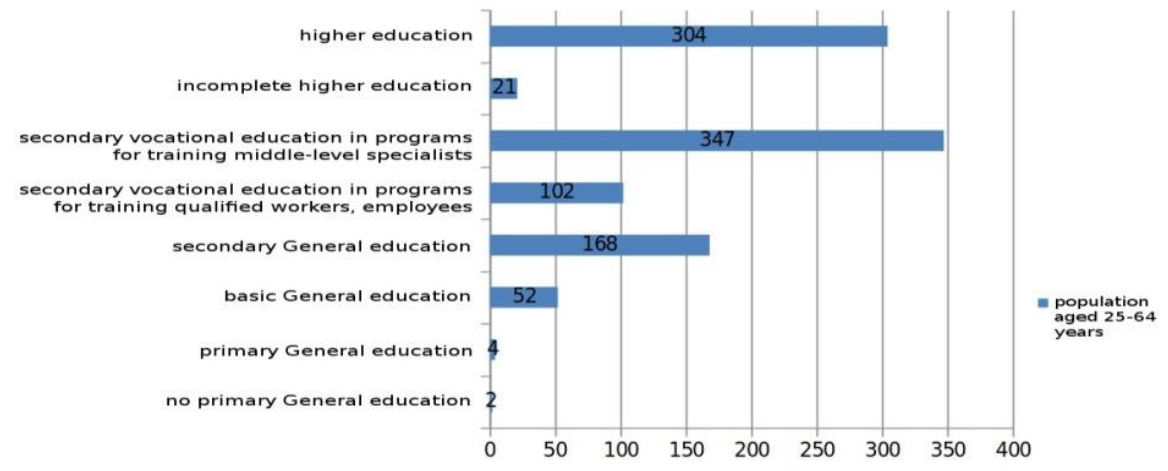

Fig. 2. Educational level of the adult population: 2015

(per 1000 people of the population of this age group, indicating the level of education) [7]

Ensuring an efficient education system requires significant financial investment. Consider the dynamics of public spending on education in Russia (table 2).

Table 2 shows that public spending on education for the period $2017-2019$, increased by 786.5 billion rubles, a growth of $24 \%$. There is an increase in funding in absolute terms and in the rate of growth for all education levels. In relative terms, funding for General education $(+313.8$ billion rubles) and pre-school education ( +242.3 billion rubles) increased most significantly. In terms of the growth rate of funding, the largest changes were shown by the following levels: vocational training, retraining and advanced training $(+81 \%)$, pre-school education $(+34 \%)$, secondary vocational education $(+26 \%)$, General education $(+24 \%)$. The highest growth rate in terms of professional training, retraining and advanced training, in our opinion, is due to the economy digitalization trend and as a result the need for students to obtain additional competencies in area mentioned.
Consider the trends in the number of students by education levels in Russia (Table 3 ).

According to Table 3, it can be seen that in absolute terms, the greatest increase is observed in the level of primary, basic and secondary general education $(+859.7$ thousand people), while in terms of growth rate, the most important is the graduation of mid-level specialists $(+6 \%)$. The growth rate for the level of primary, basic and secondary general education $+5 \%$, for preschool education $+2 \%$. The output of bachelors, specialists and masters decreased by $6 \%$, and skilled workers and employees decreased by $9 \%$. It should be noted that the rate of increase in the output of mid-level specialists and the decrease in the output of bachelors, specialists and masters coincide.

TABLE II EDUCATION SPENDING IN THE RUSSIAN FEDERATION (BILLIONS OF RUBLES) [7]

\begin{tabular}{|l|c|c|c|c|}
\hline \multirow{2}{*}{\multicolumn{1}{|c|}{ Indicator }} & \multicolumn{2}{c|}{ Years } & Changes \\
\cline { 2 - 4 } & 2017 & 2018 & 2019 & Absolute change, + - \\
\hline State expenditure & 3264,2 & 3668,6 & 4050,7 & $+786,50$ \\
\hline Preschool education & 722,5 & 841,4 & 964,8 & $+242,30$ \\
\hline General education & 1329,5 & 1471,7 & 1643,3 & $+313,80$ \\
\hline Additional education for children & 237,7 & 251,0 & 266,8 & $+29,10$ \\
\hline Secondary vocational education & 212,0 & 251,6 & 268,0 & $+56,00$ \\
\hline $\begin{array}{l}\text { Professional training, } \\
\text { retraining and advanced training }\end{array}$ & 23,9 & 33,0 & 43,3 & $+19,40$ \\
\hline Higher education & 511,0 & 554,2 & 585,2 & $+74,20$ \\
\hline Youth policy & 68,5 & 72,8 & 81,2 & $+12,70$ \\
\hline $\begin{array}{l}\text { Applied scientific research } \\
\text { in the field of education }\end{array}$ & 12,9 & 14,6 & 14,7 & $+1,80$ \\
\hline Other issues in the field of education & 146,3 & 178,4 & 183,4 & 37,1 \\
\hline
\end{tabular}


TABLE III DYNAMICS OF THE NUMBER OF STUDENTS BY EDUCATION LEVELS [7]

\begin{tabular}{|l|c|c|c|}
\hline \multicolumn{1}{|c|}{ Indicator } & \multicolumn{2}{c|}{ Years } & \multicolumn{2}{c|}{ Changes } \\
\cline { 2 - 4 } & 2017 & 2018 & \multirow{2}{*}{76019} \\
\hline $\begin{array}{l}\text { The number of pupils of organizations that carry out educational } \\
\text { activities in accordance with pre-school educational programs, } \\
\text { supervision and care of children, thousand people }\end{array}$ & 7477,9 & 7582,4 & 7606,7 \\
\hline $\begin{array}{l}\text { Number of students enrolled in educational programs of primary, } \\
\text { basic and secondary General education, thousand people }\end{array}$ & 15705,9 & 16137,3 & 16565,6 \\
\hline Output of skilled workers, employees, thousand people & 181,1 & 168,6 & 165,5 \\
\hline Graduation of mid-level specialists, thousand people & 506,9 & 531,5 & 539,8 \\
\hline Graduation of bachelors, specialists, masters, thousand people & 969,5 & 933,2 & $-15,60$ \\
\hline
\end{tabular}

In modern conditions of the development of the digital economy, the introduction of innovations, the increase in demand for computer technologies, we will consider the structure of output by enlarged groups of professions and by levels of education, we will analyse the dynamics and main trends.

Let us consider the structure of output for individual enlarged groups of professions (Fig. 3,4,5). According to Figure 3, it can be seen that from 2017 to 2019, the output of skilled workers and employees decreased slightly - from 181.1 to 165.5 thousand people.

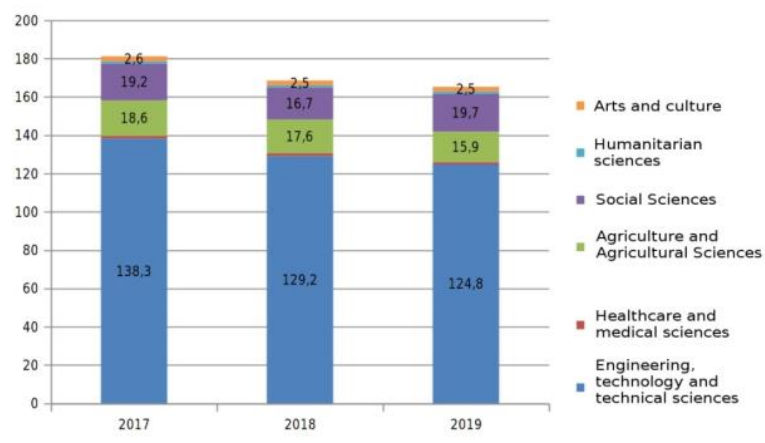

Fig. 3. The output of skilled workers, employees in individual enlarged groups of professions (thousands of people) [7]

The graduation rates of mid-level specialists showed an upward trend in absolute terms. Consider the structure of the distribution of the number of enlarged groups of professions.

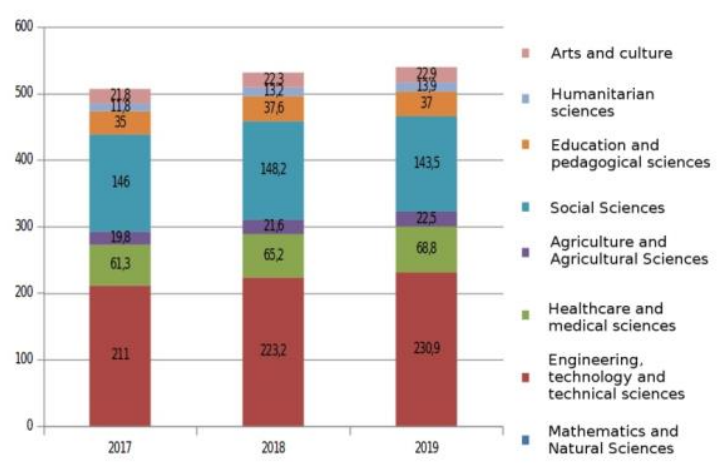

Fig. 4. Graduation of mid-level specialists in individual enlarged groups of professions (thousands of people) [7]
The following tendencies are observed in the structure of the education system output: most of all students are in the "Engineering, technology and technical sciences" professions group (tends to reduce the number from 138, 3 to 124,8 thousand people). In second place in terms of number - "Social Sciences" (tends to increase from 19.2 to 19.7 thousand people). In third place in popularity is Agriculture and Agricultural Sciences (seeks to decrease from 18.6 to 15.9 thousand people).

According to Figure 4, it can be seen that from 2017 to 2019 , the number of graduates of mid-level specialists increased from 506.9 to 539.8 thousand people. The following trends are observed in the structure: most students are in the "Engineering, technology and technical sciences" group of professions (tends to increase the number from 211 to 230.9 thousand people). In second place in terms of number - "Social Sciences" (tends to decrease from 146 to 143.5 thousand people). In third place in popularity is "Healthcare and Medical Sciences "(leans towards increase from 61.3 to 68.8 thousand people). Graduation of bachelors, specialists, masters showed a downward trend. Consider the structure of the distribution of the number of enlarged groups of professions.

According to Figure 5, it can be seen that from 2018 to 2019 , the number of bachelors, specialists, masters graduates decreased from 933.2 to 908.6 thousand people. The following tendencies are observed in the structure: students in the "Social Sciences" group of professions (the number tends to decline from 431.3 to 396.7 thousand people) constitute the majority. In second place in terms of number - "Engineering, technology and technical sciences" group (tends to increase from 245.4 to 250.4 thousand people). In third place in popularity is "Education and Pedagogical Sciences" group (to increase from 89 to 92.2 thousand people).

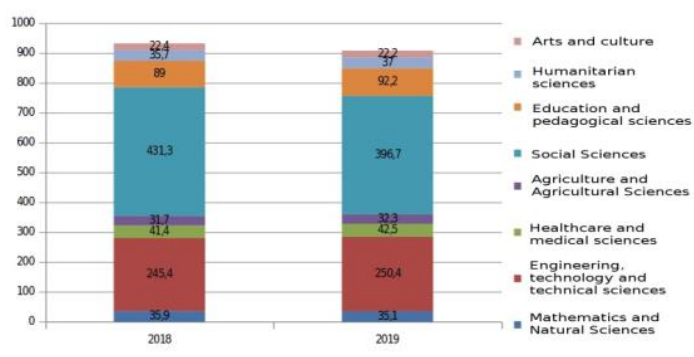

Fig. 5. Graduation of bachelors, specialists, masters in individual enlarged groups of professions (thousands of people) [7] 
According to figure 3-5, it can be concluded that "Engineering, technology and technical Sciences" and "Social Sciences" specialty groups are proving to be the most popular areas of education in modern conditions.

In the context of the digital economy development, it is quite natural that there is an increased interest in the specialties included in the "Engineering, technology and technical Sciences " group at all levels of education. It should be noted that elements of digitalization are included in the training process for other specialty groups often.
Let's look at the trends by the higher education levels : bachelor's, specialty, master's (Fig. 6). According to the figure, it can be seen that the graduation of bachelor's degree has slightly decreased - from 732.6 thousand people in 2017. up to 621.9 in 2019 , and graduation at the level of specialty and master's degree increased from 99.1 thousand people to 104.6 thousand people and from 137.8 to 182.1 thousand people, respectively.

The knowledge accumulated in the learning process should be used in practice. Let us analyze the composition of employment by the level of education (Table 4).

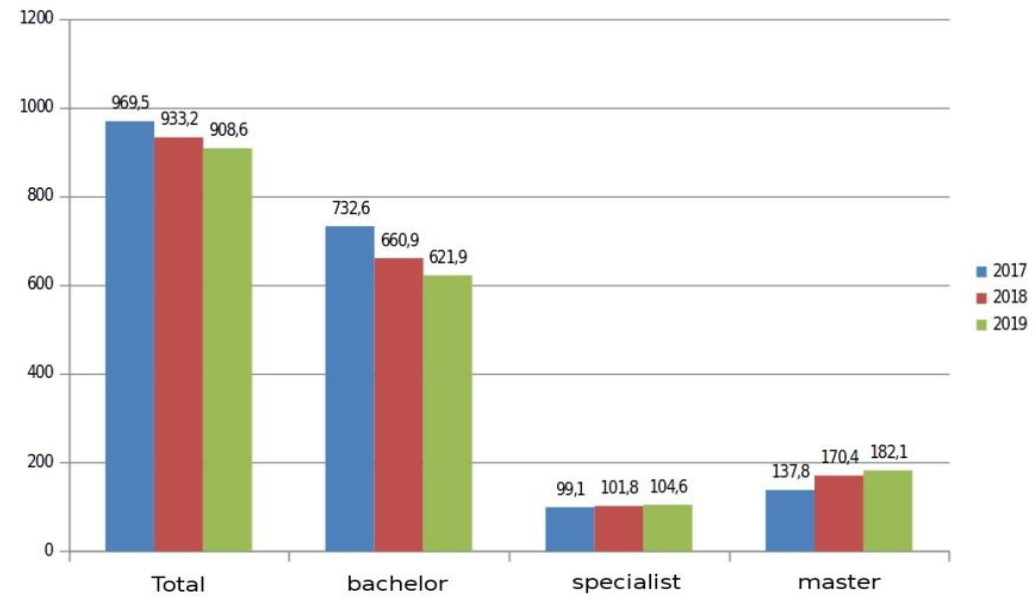

Fig. 6. Dynamics of graduates of bachelors, specialists, and masters (thousands of people) [7]

TABLE IV. COMPOSITION OF THE EMPLOYED POPULATION BY LEVEL OF EDUCATION (AS A PERCENTAGE OF THE TOTAL) [9]

\begin{tabular}{|c|c|c|c|c|c|c|c|c|c|}
\hline Indicator & Russian Federation & 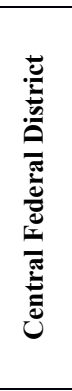 & 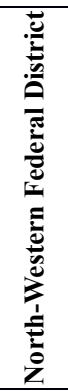 & 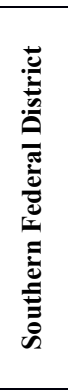 & 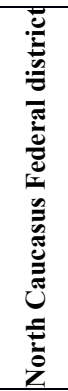 & 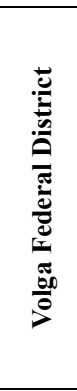 & 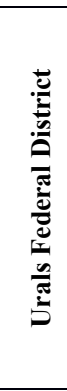 & 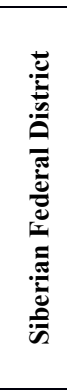 & 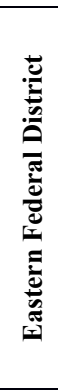 \\
\hline Employed - total & 100 & 100 & 100 & 100 & 100 & 100 & 100 & 100 & 100 \\
\hline \multicolumn{10}{|l|}{ they also have an education } \\
\hline higher & 34,2 & 39,3 & 35,1 & 30,7 & 35,5 & 31,4 & 32,5 & 30,0 & 32,9 \\
\hline secondary professional education-total & 45,0 & 44,8 & 47,5 & 44,9 & 29,8 & 48,1 & 49,0 & 43,8 & 42,9 \\
\hline \multicolumn{10}{|l|}{ from it: } \\
\hline $\begin{array}{l}\text { for training programs for mid-level } \\
\text { specialists }\end{array}$ & 25,5 & 27,0 & 23,7 & 26,0 & 20,0 & 26,4 & 27,3 & 23,6 & 24,3 \\
\hline $\begin{array}{l}\text { training programs for qualified workers } \\
\text { and employees }\end{array}$ & 19,5 & 17,8 & 23,9 & 19,0 & 9,7 & 21,7 & 21,7 & 20,2 & 18,5 \\
\hline average General & 17,2 & 13,7 & 14,3 & 20,7 & 30,8 & 16,8 & 14,4 & 20,0 & 19,1 \\
\hline basic General & 3,4 & 2,1 & 2,9 & 3,4 & 3,4 & 3,5 & 3,8 & 5,8 & 4,7 \\
\hline don't have a basic common & 0,2 & 0,1 & 0,2 & 0,2 & 0,4 & 0,2 & 0,4 & 0,4 & 0,4 \\
\hline
\end{tabular}

Based on table 4 , it can be concluded that people who have received secondary vocational education are most in demand in the labor market: by regions from $29.8 \%$ to $49.0 \%$, by the Russian Federation - 45\%. There are also high indicators for higher education: in the regions from $30.0 \%$ to
$39.3 \%$, in the Russian Federation - 34.2\%. Employees who do not have basic General education make up no more than $0.4 \%$ of the population employed; others who have only basic General education make up no more than $5.8 \%$. 


\section{CONCLUSION}

Based on the above, the following conclusions can be drawn. Human capital is a very important resource that affects socio-economic development. In the structure of human capital, the capital of education is distinguished, which is defined as a set of experience, skills, and knowledge embodied in labor activity in order to improve the quality of life of an individual, his family, and society as a whole. Education plays an important role in the human capital formation and use system at all stages: formation, accumulation, use and reproduction. The structure of education is as follows: General education (pre - school, primary General, basic General, secondary General), vocational education (secondary professional, higherbachelor's, specialty, master's, training of highly qualified personnel), additional education (additional education for children and adults, additional professional education) and vocational training. In modern conditions, the digital economy is developing, which is characterized by the increasing role of computer technologies in all spheres of life, including the education system. Taking into account the fact that ensuring the availability and quality of education is an important social function of the state, it is advisable to analyze the financing of all education levels. Analysis of statistical data showed that public spending on education in Russia for the 2017-2019 period increased by 786.5 billion rubles, growth is $24 \%$. There is an increase in funding in absolute terms and by growth rate for all levels of education. In relative terms, funding for General and pre-school education has increased most significantly. In terms of the growth rate of funding, the largest changes were shown by the following levels: vocational training, retraining and advanced training $(+81 \%)$, pre-school education $(+34 \%)$, secondary vocational education $(+26 \%)$, General education $(+24 \%)$. Growth indicators in terms of professional training, retraining and advanced training are due to the trend towards increasing digitalization of the economy, as there is a need to obtain additional competencies in this area.

A study of the education level of the adult population per 1000 people in the 25-64 age group, among those who indicated their education level, has shown that the majority has a secondary vocational education under mid-level specialist training programmes and a higher (post-secondary) education. By the number of students in absolute terms the biggest growth is observed in elementary, basic and secondary education levels, while in terms of growth rate, the graduation of mid-level specialists is the most significant. The output of bachelors, specialists and masters, as well as skilled workers and employees, has decreased. Of interest is the fact is that there is a strong correlation between the growth rate of the output of mid-level specialists and the decrease in the output of bachelors, specialists and masters.

According to the results of the output structure study, it can be concluded that in modern conditions the most popular education areas at all levels are the "Engineering, technology and technical Sciences" and "social Sciences" specialty groups. The increased interest in the specialties included in the "Engineering, technology and technical Sciences" group at all levels of education is due, among other things, to the digital economy development. Bachelor's degrees output have declined slightly in higher education, while specialist and master's degrees have increased.

Considering the fact that the acquired knowledge should be used in practical activities, that is, embodied in the employed population composition, a study was conducted on the composition of the employed population by level of education. The results of the study showed that people who have received secondary vocational education and higher education are most in demand in the labor market. Employees who do not have basic General education make up no more than $0.4 \%$ of the employed population and those who have only basic General education make up no more than $5.8 \%$ of the employed population.

The education system in Russia is developing successfully: the level of funding is increasing; the number of people who have received an education is also; in the context of the development of the digital economy, interest in the professions of the Engineering, technology and technical Sciences group is increasing; the employed population has a high proportion of people with secondary vocational and higher education. The prospects for development are further innovation and digitalization introduction in the educational process at all levels. In our opinion, it is possible to develop the direction of additional education more actively, in terms of professional retraining and advanced training to obtain and develop competencies needed to increase employment in the conditions of the economy digitalization.

\section{REFERENCES}

[1] Federal law No. 273-FZ of 29.12.2012 On Education in the Russian Federation. URL: http://www.consultant.ru/document/cons doc LAW 140174 (accessed 10.12.2020).

[2] G.S. Becker, "Investment in Human Capital: A Theoretical Analysis", Journal of Political Economy, 1962, Vol.70, № 5 (Part 2),pp. 9-49

[3] O. V. Budzinskaya, A.V. Demidova, "Human capital and investment in education”, RPE, 2016, №9 (71). URL: https://cyberleninka.ru/article/n/chelovecheskiy-kapital-i-investitsii-vobrazovanie (accessed 12.12.2020).

[4] S. G. Golovina, I. N. Mikolaychik, L. N. Smirnova, "Education as an element of human capital and a condition for successful regional development", Bulletin of the Kurgan state agricultural Academy, 2020, №2 (34). URL: https://cyberleninka.ru/article/n/obrazovaniekak-element-chelovecheskogo-kapitala-i-uslovie-uspeshnogoregionalnogo-razvitiya (accessed 10.03.2020).

[5] O. V. Zabelina, T. M. Kozlova, A.V. Romanyuk, "Human capital of the region: problems of essence, structure and evaluation", Statistics and Economics, 2013, №4. URL: https://cyberleninka.ru/article/n/chelovecheskiy-kapital-regionaproblemy-suschnosti-struktury-i-otsenki (accessed 10.01.2020).

[6] T. V. Kasaeva, D. A. Esankulova, "Education as a structural component of human capital", Scientific Bulletin of YUIM, 2020, NO. 2. URL: https://cyberleninka.ru/article/n/obrazovanie-kak-strukturnyykomponent-chelovecheskogo-kapitala, https://doi.org/10.31775/2305$\underline{3100-2020-2-12-16}$

[7] Education in numbers: 2020: a brief statistical collection, National research. Higher school of Economics, Moscow: higher school of Economics, 2020, 120 p.,200 copies. - ISBN 978-5-7598-2306-3 (in the region). URL: https://www.hse.ru/mirror/pubs/share/404878648.pdf_ (accessed 22.12.2020).

[8] Pivovarov V. I., Mazur V. V., "On the issue of human capital”, Izvestiya MSTU, №4, (18). URL: https://cyberleninka.ru/article/n/k-voprosu-ochelovecheskom-kapitale-1 (accessed 10.11.2020).

[9] Federal state statistics service.

URL: https://rosstat.gov.ru/folder/210/document/13204

[10] Kh. M. Khadzhalova, Education in the formation of human capital, UEPS, 2018. URL: https://cyberleninka.ru/article/n/obrazovanie-vformirovanii-chelovecheskogo-kapitala (accessed 10.11.2020).

[11] O. Yu. Khanova, O. K. Kudryashova, "The role of knowledge and education in the formation of human capital", Humanities, socioeconomic and social Sciences, 2014, №5-2. URL: https://cyberleninka.ru/article/n/rol-znaniy-i-obrazovaniya-vformirovanii-chelovecheskogo-kapitala (accessed 10.11.2020). 
[12] T. Shultz, "Capital Formation by Education", Journal of Political Economy, 1960, Vol. 68, No. 6, p. 571-583

[13] E. B. Nozhkina, G. A. Mavlyutova, P. L. Altukhov, "Transformation of education in the digital economy as a factor in the development of the country's human capital", Bulletin of the Saratov State SocioEconomic University, 2020, №3 (82). URL: https://cyberleninka.ru/article/n/transformatsiya-obrazovaniya-vtsifrovoy-ekonomike-kak-faktor-razvitiya-chelovecheskogo-kapitalastrany (accessed 10.11.2020).

[14] Difficulties and prospects of digital transformation of education, National Research University Higher School of Economics, Institute of Education, Moscow, Ed. House of the Higher School of Economics, 2019, 343, URL: https://ioe.hse.ru/data/2019/07/01/1492988034/Cifra text.pdf

[15] P. Bourdieu, Forms of Capital, Handbook of Theory and Research for the Sociology of Education. URL: http://www.socialcapitalgateway.org/content/paper/bourdieu-p-1986forms-capital-richardson-j-handbook-theory-and-research-sociologyeduc (accessed 10.11.2020).

[16] T. Tolstykh, "Assessment of the Impact of Higher Education Development on the Social and Economic Processes in the Region", Proceedings of the 29th International Business Information Management Association Conference (IBIMA), 3 - 4 May, 2017, Vienna Austria. 2017, p. $2180-2191$. 